\title{
Monster Cows and the Doing of Modern Biotechnology in Sweden: An Intersectional Risk Analysis
}

\author{
Anna Olofsson, Susanna Öhman \\ Risk and Crisis Research Centre, Mid Sweden University, 83125 Östersund, Sweden \\ E-mail: anna.olofsson@miun.se
}

Received 22 September 2016

Accepted 15 October 2016

\begin{abstract}
In this article, the aim is to analyse how the insemination of images of a cow is entangled with perceptions of gene technology through the 'doing' of risk, nature, periphery and gender in Sweden. Two types of data have been used; the 1996 Eurobarometer survey on public opinion and a corpus of articles from the Swedish daily press. $13.6 \%$ of the respondents thought about the Belgian Blue cattle in relation to gene technology. Those who associated to the 'Belgian Blue' were more negative to gene technology on a general level, but did not differ from the rest of the sample in their attitudes to the specific applications of gene technology. Only one media article states that Belgian Blue is genetically modified, while $13 \%$ mention that the breed has a genetic defect, and almost all of the articles are very negative to the breed. The mass media achieved its most significant effects by (re)creating meanings and frames, frames which the public participated in cocreating and which were sometimes incorporated by the individual into his or her personal understanding of gene technology, in this case, the Belgian Blue as an image of gene technology. The conclusion was that terms like gene technology are so abstract that people have problems in understanding the meaning of the concepts and then turn to easily accessible images for instance in the media.
\end{abstract}

Keywords: Intersectional risk theory, Gene technology, Media analysis

\section{Introduction}

In 1995, Swedish newspapers published reports about a farmer who was planning to import twentyfive Belgian Blue bulls to Sweden (Olofsson and Olsson 1996, Öhman 2002). ${ }^{1}$ The media debate about gene technology and the 'monster bulls' that followed this first report did not only question the

\footnotetext{
${ }^{1}$ These cattle originated in central and upper Belgium, and the breed was established in the early $20^{\text {th }}$ century. The breed was divided into two strains, one primarily for milk production and the other a beef animal. In the late 1950 s, a debate ensued among breeders, the question being whether to maintain the dual-purpose type as it was or to select more muscling. Selection is now primarily for beef, and at 24 months, a male weights about $1,700 \mathrm{lb}$. There is a large proportion of muscle hypertrophy in the Belgian Blue, which is genetically inherited, meaning that the animals are born with double thigh muscles that grow more meat and yield greater productivity. Muscle hypertrophy also makes the internal organs of the animal smaller and the need for delivery by caesarean is frequent. The Belgian Blue consists of about $45 \%$ of the national stock of Belgium; nine other counties have registered animal stocks, and sperm and embryos are exported to about 25 additional countries mainly for crossbreeding with milk cows (Ljungdahl and Sonesson, 1995).
}

then relatively new technology but everything from the ethics of modern farming to Sweden's new membership of the European Union. The editor of the evening tabloid Expressen wrote: The Belgian monster-bull, with double thighs and legs so weak that it can't stand up by itself, will be imported to Sweden. Risk of 'bull-rush' against EU regulation (Expressen, 1995-09-16, p. 2.). This media debate would have a significant impact on how gene technology was perceived in Sweden in the following years (Self reference). In this article, we will analyse how the insemination of images of a cow is entangled with perceptions of gene technology through the 'doing' of risk, nature, periphery and gender.

Sweden prizes itself as a nation of nature and animal lovers, which is not only expressed in people's leisure activities, such as hiking or picking berries, but also in terms of public opinion and the Swedish Animal Protection Law. ${ }^{2}$ Nature is

${ }^{2}$ The Swedish Animal Protection Law forbids e.g. animal breeding that can cause suffering to the animal or influence the animal's natural behaviour (SFS 1994:904). The Ministry of Agriculture has therefore forbidden all uses of the Belgian Blue in Sweden. 
perceived by many as sacred, and local products are often preferred and idealised. Against this backdrop, it is not surprising that the importation of bulls that resemble the stereotypical unnatural breed was taken up by the media. The attention was on the breed's physical characteristics, e.g. a giant body with large muscles, weak legs and small internal organs, as well as the breed's calving problems (it has to deliver by caesarean section). Newspapers nicknamed the bulls 'monster bull' and 'gigantic monster', among others, and it is not surprising that the public reaction was negative. What is more surprising is that it became so tightly associated with gene technology despite the fact that the breed got its characteristic look from a combination of a 'natural' genetic defect, which increases the production of muscles, and 'traditional' breeding techniques in the early twentieth century. As such, it was not genetically modified using modern biotechnology. In a 1996 Eurobarometer survey, respondents were asked: What comes to mind when you think about gene technology in a broad sense? More than 13\% answered: the 'Belgian Blue monster bull'. ${ }^{3}$ Other 'images' of gene technology were also found in the study, such as 'human monsters', 'eugenics', 'progress' and 'tampering with nature'. However, the Belgian Blue was not mentioned in any other European country. This seems to imply that the Belgian Blue is a unique Swedish image of gene technology. The relation between public perceptions and media content is, as we know, far from clear, but in this case, we find interesting interrelationships which are worthy of further analysis (Lowerty and De Fleur 1988; McQuail 1994; Asp 1986).

\section{Mass media and how a monster cow is 'done'}

The question about the mass media's influence over society and its inhabitants is not new, and after almost a century of research, the answers remain fairly ambiguous (McQuail 1994). Some argue that mass media research has gone through three phases in terms of the impact of the mass media on society and individual citizens: the 'almighty media' and its

\footnotetext{
${ }^{3}$ At the time, the authors were part of an international research project, 'Biotechnology and the European Public', in which the 1996 Eurobarometer survey was conducted.
}

direct impact in terms of what is written in the newspapers will be picked up by the readers; the 'powerless media' - since it was difficult to prove the relation between media content and readers' perceptions, the conclusion was that the mass media has no impact; finally, the return of the "powerful media' (Asp 1986; Gutteling and Wiegman 1986). The last view is also the dominant view today as the mass media is seen as having its most significant effects as it (re)creates meanings and frames frames which the public participates in co-creating and which are sometimes incorporated, and sometimes not, by the individual into his or her personal understanding of the world. However, journalists are, of course, members of society; they engage in normative and value-laden discourses like everyone else and draw on these social and cultural resources when selecting what to cover and what not to cover and how to frame the chosen news items. Other actors and institutions are also involved in this process of meaning production through media and other channels (Bauer 1995; Ruhrmann 1992). Thus, the mass media plays an important role in individual and social meaning production, and even if these media do not control public opinion, they are part of the hegemonic discourses; they offer, or at least make available, frames and information for creating subjective understandings of the world around us (Gamson and Modigliani 1989).

Media discourses can be seen as sets of interpretative packages that give meaning to an issue or event and that offer a number of different symbols that indicate a core frame and make it possible to expose the package as a whole (ibid). In this way, journalists and other actors with power to influence mass media output (re)produce norms regarding, for example, gender, origin, weight and centre versus periphery (Giritli-Nygren, Öhman and Olofsson 2016; Montelius and Giritli-Nygren 2014; Olofsson 2011). In other words, mediated discourses are interpreted and (re)produced, and when these discourses relate to risk and crises, they simultaneously 'do' risk and gender, ethnicity, class, etc. (Giritli-Nygren and Olofsson 2014, Olofsson et al. 2014). To 'do' risk means to socialise normative constructions of risk anchored in time- and context-dependent beliefs about society and its inhabitants that influence both how society is organised and governed and how we as individuals live our lives. In this process-it is a 
process because the notions of risk are constantly negotiated and thus always changing-risk is 'done' and 'undone', and risk is attributed to certain groups and individuals. These groups and individuals are portrayed as 'risky' or 'at risk', but others are not (on 'doing risk', see Giritli-Nygren and Olofsson 2014: p. 1121).

In the field of science and technology, the media's role of offering handy images become clear. Situations in which people are dependent on mass media to receive information, it is also more likely that mass media will influence public perception and debate (Gutteling and Wiegman 1986). Many people have limited personal experience and use the frames delivered by the mass media to understand and relate to such phenomena (Nelkin 1995; Asp 1986). Gene technology is a typical example of a 'highthreshold' issue, that is, an issue or event whereby it is difficult for the general public to gain knowledge through any other sources than news media (Lang and Lang 1991) since it is a relatively new and complex technology. The flvr-savr-tomato, Dolly, the Belgian Blue bull and genetically modified mosquitoes used to fight diseases from viruses have, over the years, all become public images of gene technology in Sweden, not by personal acquaintance, but by the information provided by the electronic and print media. This also implies that the public has little conception of the reality of the gene technology available other than what the media offers. In a study on the differences in risk perceptions between people with personal experiences and people without, it was shown that the latter group was influenced by mass media to a larger extent than the first group, or in Dorothy Nelkin's (1995) words: 'Public beliefs about science and technology tend to correspond with the messages conveyed in the media, though the direction of cause and effect is not clear'. Needless to say, the images associated with gene technology have not only become public images simply because they refer to the scientific development, they correspond to the media's logic in choosing what is new.

Research has shown that science and technology become newsworthy when they are part of wider social and political arenas and when they are linked to major accidents and disasters (Hansen 1994; Friedman 1986). One important criterion concerning scientific news is whether it has a human angle, which gives subjects like medicine, scientific-technical innovations and food-related issues more media attention than is given to other research subjects (Hansen 1991). Although quality press covers science to a greater degree and in an in-depth manner, the main object for a journalist is to write articles that will capture the attention of readers, listeners or viewers. As a consequence, in order to make articles more entertaining, the selection of news covering science and technology often focuses on drama, peculiarity and controversy (Hansen 1994; Kohring 1998; Nelkin 1995). There are also studies indicating that news coverage, over time, has become more critical towards science and technology, although this might be the case of a general change in media coverage and that today's science news is just news among news in general (Kepplinger 1992; Djerf Pierre 1996).

\section{Materials}

Two types of material were used in this study: a survey on public opinion and a corpus of articles from the Swedish daily press. The 1996 Eurobarometer survey on gene technology was used to measure public opinion on gene technology in general. The survey was conducted in 15 European countries, including Sweden. The Swedish part of the survey consisted of 1,008 interviews representing the population over the age of 15.These were conducted between November 02 and 22, 1996. Both general questions about gene technology and questions about more specific applications were posed. The survey also contained questions about attitudes, knowledge, trust and regulation as well as an open-ended question concerning free associations with the concept gene technology.

To map the media image of the Belgian Blue, the five most read and influential newspapers in Sweden were selected: three quality morning papers, Dagens Nyheter, Svenska Dagbladet and GöteborgsPosten, and two evening tabloids, Expressen and Aftonbladet. To obtain a comprehensive picture of the coverage of the Belgian Blue, all relevant clippings published were selected and examined via the on-line full-text archive Mediearkivet (Retriever). Articles dealing with 'Belgian Blue', 'belgisk blå', 'monstertjur/ko' (monster bull/cow) etc. were selected. This can be described as the total body of articles with the Belgian Blue as their main subject. The first article 
found was published in early 1992, and the search ended when the survey was fielded in late 1996, resulting in 84 articles. A total number of 84 articles were published during the time of study, of which 80 focused primarily on the Belgian Blue. One of the papers, Dagens Nyheter, was also searched for articles concerning gene technology in general to ascertain the extent to which the Belgian Blue featured in articles about gene technology. Dagens Nyheter published 66 stories about gene technology and 26 articles about the Belgian Blue, but only one article connected the two issues. This single article is actually the only publication in the sample that mentions the Belgian Blue in relation to gene technology.

The size of the articles can tell something about the attention given to the issue, and in this case, more than half of the articles, 52, were small or news items. Few were large (only two), and the remainder were medium sized. However, in this case, article size was counted without possible pictures, and at least half of the articles were published together with a picture of a Belgian Bluebull. This suggests that more than 40 articles had attention drawing attributes even though they might not have included a large amount of text. Much of the media attention given to the Belgian Blue focused on two real world events: the importation of 25 bulls and the insemination of Belgian Blue sperm into Swedish cows. The following narrative gives the picture of how the press framed these events, the issues at stake and the persons involved. It is a story based on quantitative and qualitative content analysis along with inputs from the analysed newspapers.

Content analysis was employed on the stories whereby a coding frame consisting of eight variables, including size, date, page type, author, pictures, themes and valuation tone was used (see Gamson and Modigliani 1989; Krippendorff 1980). Themes were first coded as an open variable whereby all sorts of themes in the articles were written down; thereafter, ten different categories were created. The evaluation tone was coded as 'neutral', 'positive' or 'negative' based on the dominant impression of the article. The dominant view was coded if an article contained both positive and negative arguments, but if the arguments were balanced, i.e. had the same degree of strength, or no evaluation was made, the article was coded as neutral. To elucidate how the cow was 'done' from an intersectional risk approach, a qualitative content analysis was also employed for a selection of stories. To identify relevant articles, we read all the articles and then read through a small number of articles from each newspaper to get a deeper understanding of the media frame. Several readings were then undertaken to identify themes in the articles (Geertz 1973).

\section{Results, or, how a cow can 'do' risk perceptions}

First, the results from the media analysis are presented together with examples from the newspaper articles. Thereafter, we describe how images of a particular kind of cow, the Belgian Blue, becomes entangled with perceptions of a new technology, gene technology. Finally, a few figures on media habits are presented.

\subsection{Mass media as sources of images}

If we look at mass media images of the Belgian Blue, we find that the coverage was not extensive, but the issue did attract some attention. The first article was published as early as the beginning of 1992, and it referred to a TV programme about animal welfare in Europe. This, and another similar story later on in the beginning of 1995, did not trigger media attention in any broader sense. The real breakthrough came the autumn of 1995 with the news that a Swedish farmer was planning to import twenty-five Belgian Blue bulls. Still, it was not a 'big' story; only 15 articles were published in the five newspapers altogether. An overview of the results is given in Table 1. 
Table 1. Summary of results from the media content during the period of study. The sample of headlines aim to give the reader a better picture of the three periods. ${ }^{a}$

\begin{tabular}{|c|c|c|c|}
\hline & IMPORT OF BULLS & INSEMINATION & POST INSEMINATION \\
\hline TIME PERIOD & $15 / 09 / 95-28 / 02 / 96$ & 01/03/96-30/05/96 & 01/06/96-19/11/96 \\
\hline NUMBER $^{b}$ & 15 & 44 & 23 \\
\hline $\begin{array}{l}\text { MORNING/EVENING } \\
\text { PAPER }\end{array}$ & $9(60 \%) / 6(40 \%)$ & $28(64 \%) / 16(36 \%)$ & $19(83 \%) / 4(17 \%)$ \\
\hline \multirow[t]{3}{*}{ THEMES } & Defects $23 \%$ & Breeding $25 \%$ & EU $17 \%$ \\
\hline & Laws/Reg. $19 \%$ & The farmers $18 \%$ & Laws/Reg. $15 \%$ \\
\hline & Weight $15 \%$ & Laws/Reg. $16 \%$ & Breeding $15 \%$ \\
\hline \multirow[t]{3}{*}{ VALUATION } & Negative $100 \%$ & Negative $68 \%$ & Negative $52 \%$ \\
\hline & & Neutral $30 \%$ & Neutral $43 \%$ \\
\hline & & Positive $2 \%$ & Positive $4 \%$ \\
\hline $\begin{array}{l}\text { MONSTER-BULL } \\
\text { MENTIONED }\end{array}$ & $100 \%$ & $84 \%$ & $61 \%$ \\
\hline $\begin{array}{l}\text { GENETIC DEFECTS } \\
\text { MENTIONED }\end{array}$ & $33 \%$ & $9 \%$ & $9 \%$ \\
\hline HEADLINES & 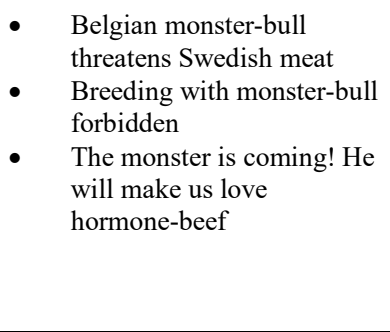 & $\begin{array}{l}\text { Meat from Belgian Blue } \\
\text { boycotted. Four cows have } \\
\text { been inseminated with } \\
\text { sperm from the monster- } \\
\text { bull. } \\
\text { She will give birth to the } \\
\text { monster calf. Swedish cows } \\
\text { are inseminated - the } \\
\text { minister threatens to } \\
\text { prosecute. }\end{array}$ & $\begin{array}{l}\text { - The EU puts animal } \\
\text { protection out of play. } \\
\text { - Impossible to stop Belgian } \\
\text { monster-bull } \\
\text { - } B \text { elgian Blue-calf' died } \\
\text { during delivery }\end{array}$ \\
\hline
\end{tabular}

${ }^{a}$ Percentages were used to make comparisons between the periods possible, but it is important to note the small number of articles.

${ }^{b}$ Articles published before 15 September 1995 were not included.

The table shows both differences and similarities between these three periods. Over time, the coverage became less negative, and the expression 'monsterbull', which was mentioned in all articles in the first period, was only mentioned in $61 \%$ of the articles in the last. In the initial period, many articles focused on different defects of the breed, and in the second period, breeding and farmers were on the agenda. The third period did not focus on a specific topic, although the EU and regulation were awarded large amounts of space, but the Belgian Blue had become a metaphor for something else - someone or something that was unnaturally strong.

One of the more interesting findings is that only one out of the 84 articles stated that the Belgian Blue was genetically modified. Instead, about $13 \%$ of the articles mentioned that the breed had a genetic defect. In the initial period, one-third of the articles mentioned genetic defects. This figure then decreased to about $10 \%$ during the following two periods. However, it is important to note that only a single article made a connection with modern biotechnology, or gene technology (a connection the does not exist). All other articles either mentioned a genetic defect or made no mention of genes.

If we compare the morning newspapers with the evening ones, there are almost no differences except that the evening newspapers focused more on two farmers Nilsson and Hagelgren. The general lack of difference shows that the same story was covered in both newspaper segments. Considering that these were the largest newspapers in Sweden influencing readers of local and regional media and users of other kinds of media such as television and radio, we can assume that the picture given here is pretty much the same as that given in many other media channels. In what follows, we present an analysis of the three periods.

Dagens Nyheter published one of the first articles about the importation on 15 September 1995, and it was typical for articles published that autumn:

The disputed Belgian 'monster-bull' Belgian Blue is on its way to Sweden. The breed is so heavily built that the animals normally have to give birth by caesarean - and be slaughtered before the legs break. (...) According to the magazine, Land, the first specimen of the Belgian Blue will arrive in Sweden next week. Via an importer in Jönköping, 
25 bulls will be transported to quarantine in Skåne before they are sold to interested framers. The importation of the bulls is fully legal as a consequence of Sweden's entry into the EU. Earlier, the breed was forbidden. (Dagens Nyheter, 95-09-15, p. 8)

This event was responsible for making a breakthrough in the media; the debate was initiated by the quality morning newspapers, the same newspapers which published the largest number of articles. However, evening papers were soon to follow, and all newspapers placed emphasis on physical defects, regulation and animal welfare. The articles published during the latter part of 1995 were very negative and framed the breed as a 'monster-bull' not suitable for Swedish farming, something that the EU forced Sweden to accept despite breaking the Swedish animal protection regulation.

All the articles during this time used the frame 'monster-bull' and focused sharply on the different defects and physical problems with the breed. In one-third of the stories, the genetic defect, which gives the breed its extra muscles, was mentioned: The critique against the Belgian Blue is that the over-sized breed is a genetic defect (Dagens Nyheter, 1995-11-07, p. A05). In the coverage, the EU was often mentioned as an external authority that forces Sweden to accept this clearly unacceptable breed of cows. Hence, the defects and genetic defects, more specifically, were linked to broader frames of authority and governance related to the then-recent Swedish EU membership; the introduction of the Belgian Blue in Sweden was an example of the bureaucratic straightjacket of EU membership, and the image of the bull came to be associated with the negative frames of EU governance at the time.

The second event was the insemination of four Swedish cows with sperm from Belgian Blue-bulls. The insemination was undertaken 30 March 1996, and the media followed the story for about 14 days. Twenty-five articles were published in the five newspapers during this time, and throughout the entire 'insemination period', 44 articles were published. An example follows:

For the first time, germs from the disputed breed Belgian Blue were introduced to the Swedish cow stock. This happened in Viken in Skåne where four cows were inseminated with sperm from the 'monster-bull' in spite of powerful protests from several societal actors. (Svenska Dagbladet, 199603-31, p. 8)

During this time, the issue of animal protection was still on the agenda, but many of the stories described the event of the insemination and other breeding aspects. The articles were negative, but the number of neutral stories increased during this second period. Not all articles framed the bull as a 'monsterbull' ( $84 \%$ of the stories included the word), and less than $10 \%$ wrote about genetic defects.

The two main actors Gunnar Nilsson, the man who inseminated his cows, and Per-Olof Hagelgren, the importer of the sperm, received a great deal of attention, especially from the evening newspapers. The media gave them nicknames like 'the sperm farmers' and 'pig (bull)-headed'. Several stories covered the prosecution of Gunnar Nilsson for breaking the Swedish animal protection law, and the Swedish Minister of Agriculture, Annika Åhnberg, even promised to put an end to the inseminations.

It is with horror and disgust you can see these greedy, emotionless Skåne farmers, who inseminate sperm from the bastard Belgian Blue, in the mass media! (...) Don't ever buy a single steak of the monster animals! (Göteborgs-Posten, 1996-04-09, p. 4)

By this time, the importation of the Belgian Blue had engaged environmental and animal protection groups, and at the time of the insemination, people had gathered to demonstrate. The situation quickly developed into something much more than questions concerning right versus wrong in relation to Swedish versus EU regulation. This issue generated such strong reactions that Gunnar Nilsson even received death threats. At the time of the insemination, the inseminator tried to conceal her identity by covering her face - no one wanted to be connected to the event.

The insemination remained on the agenda in many of the articles published later in 1996, and one can argue that it was the main event. The period following the insemination did not cover any specific event but was rather a sequel of both the importation and the story of the insemination. Breeding remained on the agenda, as well as laws and regulations, and during this period, the controversy between Swedish and EU regulations was once again in focus. 
Per-Olov Hagelgren and the farmer, Gunnar Nilsson, in Viken in the outskirts of Helsingborg are, together with a female veterinary assistant from Kristianstad, being prosecuted for violating the animal protection regulations. (...) Hagelgren refers to the fact that there are no prohibitions or restrictions according to the EU Council's directive concerning approval of pure-bred breeding-stocks. (Expressen, 1996-06-12, p. 21)

The citation above also illustrates that the story was located in a peripheral frame and was entwined with several layers, including gender. It was the peripheral position of Sweden in relation to the EU; thus, the Belgian Blue was forced upon Sweden by EU legislation. Later, greedy farmers from the periphery or outskirts of the country immorally imported and inseminated the new breed. As often seen in this kind of coverage, rurality was also linked to particular gender stereotypes (Öhman, Giritli Nygren and Olofsson 2016), not least the wrongheaded male, less-knowing hill bill. Notwithstanding, here, the farmers were also linked to frames of marketisation, morality and greed. There was no mentioned, taken-for-granted centre, with high morals, with the right to judge not only the farmers but also the new EU-authority. The centre was represented by the newspapers themselves as well as the minister of agriculture, who was horrified by the acts of the two avaricious, immoral farmers.

The total number of articles decreased to 23 during the period between the insemination and the time of fielding the survey. About $50 \%$ of the articles were negative, with a similar proportion being neutral and four percent being positive. Less than two-thirds used the phrase 'monsterbull', and only nine percent of the articles mentioned genetic defects. At the same time, the image of the cow had become established, and the newspapers used the Belgian Blue as a metaphor for big and strong (or mean) male hockey players and the like.

Taking the coverage together, one frame stood out - the (un)naturalness frame. Needless to say, the breed was pictured as unnatural due to its double thighs and its inability to give birth without assistance. However, the frame intersected with ideas of gender and birthing in interesting ways. One observes an ambivalence between the image of a big and muscular 'bull' as a metaphor for supernaturally strong males and that of the cow being violated by the insemination without being able to give birth. It is not the bull that violates the cow; rather, it is the bull that is at once big and strong and violated and vulnerable. Hence, there is not really a female perspective in the story of the cow that cannot birth its own offspring. The (un)naturalness frame is also strongly related to images of monsters, male monsters like Frankenstein, which is interesting considering the difference regarding another modified animal at the time, Dolly - a (in fact) genetically modified sheep, which was a clone of her own mother. In the case of Dolly, metaphors of female virgin birth and female sexuality, and fertility more generally, impregnated the media coverage (Einsiedel et al. 2002). It was as if the big muscles of the Belgian Blue overrode the female perspective of birth and made the Belgian Blue un/one-gendered.

\subsection{The Belgian Blue and the perception of gene technology}

In the survey, we asked what came to mind when people thought about modern biotechnology in a broad sense, including genetic engineering. A total of $13.6 \%$ of the respondents mentioned the Belgian Blue or synonyms like monster bull in response to the prompt. Apart from the image of the monster bull, we also constructed some image clusters; 'human monsters', 4 'eugenic', 5 'tampering with nature' ${ }^{6}$ and 'progress'. 7 None of these clusters came up more frequently than the Belgian Blue image: 'tampering with nature' $(10.5 \%)$, 'progress' (8.6\%), 'human monsters' $(6.5 \%)$ and 'eugenic' (4.3\%). Only 'progress' constituted a positive frame; the remainder of the images were mostly negative, which corresponds with earlier research (Olofsson and Olsson, 1996; Fjaestad and Olsson 1997, Öhman 2002). In the following results, we focus on the Belgian Blue image and only briefly describe the results for the other image clusters.

If we look at the Belgian Blue image, we see negative associations from the respondents. The most common association was monster bull, but

\footnotetext{
${ }^{4}$ This category consists of threatening images about humans, e.g. designer babies, producing the perfect worker, etc.

${ }^{5}$ E.g. Hitler would have liked to produce certain qualities in humans for special purposes, etc.

${ }^{6} \mathrm{E}$.g. It is unnatural, disturbs the natural balance, interferes with natural laws, etc.

${ }^{7}$ E.g. Gene technology will make life easier; biotechnology is scientific progress, etc.
} 
expressions like freak and deformed beef cattle were also mentioned. Other negative associations included unnatural, horrible, terrible and disgusting.

'Those cows, the monster bull from Belgium'.

'The grotesque Belgianbull'.

'I think of the big cows, Belgian Blue, unnatural'

Other facts were expressed, such as the Belgian Blue not being able to give birth in a natural way and that the bulls were plagued with mobility problems.

'I think about the Belgian Blue - monster bulls which must be delivered by sawing the cow in half'.

'Too many animal manipulations, for example, the cow that is so big that it cannot support its own weight; it is sick'.

More neutral wordings were 'big bulls/cows', 'new cows' and 'breeding'. One of the respondents referred to the Belgian Blue as the 'EUcow', and many of them connected the Belgian Blue with gene manipulation. Some also said that gene technology had gone way too far in creating monsters like the Belgium bull.

'The little I've heard is when they genetically manipulate the big giant bulls, the Belgian Blue'.

These results demonstrate that people relate gene technology to the image of something perceived as monstrous, something big, something new and, most specifically, as the Belgian blue or what some people called 'the monster bull'. This connection existed although, as we have shown, the newspapers did not make the explicit connection between the breed and gene technology. The images were anchored in frames of what was natural and what was not and, to some extent, in relation to the European Union and how the union forced new rules, in this case, technology, on Sweden and Swedes. We wanted to see what this image 'does' with people's perception of the new technology and compared people who connected gene technology with the Belgian Blue to people who did not in order to investigate whether there was a relationship between this image and perceptions of gene technology. Before the openended association question, a general question was asked about the way in which science and technology change our lives, for example, 'modern biotechnology'. ${ }^{8}$ The respondents were asked to state whether they thought biotechnology would 'improve our way of life in the next 20 years', whether it would 'have no effect', or whether it would 'make things worse'. These will be referred to as general attitudes in the following results.

The 'Belgian Blue image group' had more negative attitudes towards gene technology than the other image clusters. On a three-point scale, the 'Belgian Blue image cluster' had a mean of 1.80 and the others a mean of 1.56 (F-ratio 7.68, $\mathrm{p}<0.05)$. There were no differences between the groups in terms of the other science and technology areas. This indicates that the image of the Belgian Blue was related to the public's general negative opinion of gene technology but not to technology in general. If we look at the other image clusters, the relations appear different. The cluster 'tampering with nature' did not only relate to general attitudes to gene technology; there was no difference between people with this image and the remainder of the respondents in terms of their specific attitudes towards the applications of gene technology. However, 'human monsters', a threatening image concerning humans, were both related to gene technology in general and specific attitudes towards applications of gene technology. It is interesting to see that people with this image were significantly more negative towards applications crossing the boundaries between plants, animals and humans. They were more negative towards xenotransplants and the introduction of human genes into bacteria to produce medicines. Both these applications can be conceived as manipulations, and perhaps alterations, using humans. The smallest image cluster 'eugenic' had the same pattern as people associating with Belgian Blue, that is, a significant relation in terms of general attitudes to gene technology and no relation to the other technologies.

The only positive image cluster 'progress' was very different from the negative clusters with regards to specific applications. People with 'progress' images were significantly more positive than the remainder of the respondents in all six applications of gene technology, medicine, gene testing, laboratory animals, xenotransplants, novel food and crop plants. For the question 'what comes

${ }^{8}$ Modern biotechnology and gene technology are used synonymously in the text. 
to mind when you think about gene technology in a broad sense', they also mentioned twice as many biotechnological applications as the remainder of the respondents and significantly more medicaland less animal-related applications.

In the context of media habits, the 'Belgian Blue image group' read both quality papers and tabloids more than the remainder of the sample. Twentyeight percent read quality papers and 34\% tabloids compared with the others, of which $22 \%$ read quality papers and $25 \%$ tabloids $\left(\mathrm{Chi}^{2} 11.70\right.$, $\mathrm{p}<0.05)$. The 'Belgian Blue image group' also indicates that over the previous three months, they had read about issues involving gene technology in the newspapers to a greater extent than the remainder of the sample: $36 \%$ compared to $28 \%$ $\left(\mathrm{Chi}^{2} 3.49, \mathrm{p}<0.05\right)$.

\section{Discussion}

As we have shown, the media coverage of the Belgian Blue became quite intense at certain points: the importation and the insemination of the cows. The picture portrayed by the media was mostly negative, or very negative, describing the new breed as unnatural and monstrous. Respondents to the survey gave similar descriptions, for example: $I$ think about the Belgian Blue - monster bulls which must be delivered by sawing the cow in half. Only a few days before the survey was fielded, Aftonbladet published a story about this event with the headline: Calf slaughtered with chain saw-inside the cow.

The media coverage constructed a picture of an animal with several unusual and sometimes bizarre characteristics based on a genetic defect. This media construct was framed in the context of the animal loving Swedish society. People then reconstructed this image through personal knowledge, experiences and emotions, and the output was their personal picture of the Belgian Blue. For some, this image was closely related to gene technology. Even though the press has not written that the Belgian Blue was a genetic modification, the use of the term 'genetic defect' could have led to associations with gene technology since general knowledge was low. The Belgian Blue was depicted as a strong monster, a bull bigger than all other bulls but, at the same time, vulnerable. The big bulls could not be delivered without caesarean section or even a chain saw. This clashing picture may have been the reason for the negative attitudes evoked by the images. The mass media achieved its most significant effects by (re)creating meanings and frames, frames which the public participated in co-creating and which were sometimes incorporated by the individual into his or her personal understanding of gene technology, in this case, the Belgian Blue as an image of gene technology.

Even though the Belgian Blue was the most common image of gene technology among people, there were also other images, most of which were negative. Two of them, 'tampering with nature' and 'progress', seemed to represent more general attitudes to technological development, the former negative and the latter positive. People associating gene technology with progress also perceived the different applications of gene technology as more favourable than the others respondents. This indicates that people with this image had more stable cognitive-based attitudes to gene technology, and the general attitude did not differ from specific attitudes to different applications.

If we turn to people's associations of the Belgian Blue, the pattern looks different. While these people had more negative general attitudes to gene technology than the remainder of the respondents, there was no difference in terms of the six applications of gene technology. This seemed to be an example of less stable and more emotionallybased attitudes.

People in general did not know very much about gene technology, and as a result of the lack of awareness, attitudes might have been diffused and perhaps unstable. We think that terms like gene technology or modern biotechnology are so abstract that people have difficulty grasping and understanding their meaning. People have had to rely on their own ability to define and conceptualise ideas like gene technology based on the available information, in this case, mainly from the media. If we turn to attitudes towards specific applications of gene technology, the case is different. The attitude object is clearer; people knew more about similar situations, e.g. the development of new medical treatments, and could more readily relate to the object. As argued earlier, knowledge and involvement increase people's capacity to understand attitude objects, which can potentially marginalise, for instance, the impact of the media.

Twenty years after the introduction of Belgian Blue cattle in Sweden there is still strong feelings about the breed. The slaughterhouses has made 
statements that they will not slaughter Belgian Blue cattle or crossbreeds with Belgian Blue and the farmers organisation LRF has also been negative towards the breed (Expressen, 2010-02-11). Even though the public opinion about the breed in Sweden is still negative the estimate is that about one percent of beef sold in Sweden today comes from crossbreeds with Belgian Blue (Lantbrukets affärstidning, 2015-03-17). To avoid problems with calving, usually the combination of Swedish milk cattle and Belgian Blue is used (Svenska Dagbladet, 2006-10-27). The breeding is also done in secrecy and the meat is not labelled as coming from Belgian Blue cattle to avoid negative public reactions. The debate that the introduction of Belgian Blue cattle started twenty years ago is not forgotten and still influences the public's attitudes to food and food production.

\section{Acknowledgements}

The authors acknowledge funding for this study from the Erinaceidæ Foundation and the MagnBergvalls Foundation. We also want to express our appreciation to our senior colleague Professor Björn Fjæstad. The article is partly based on material from the 1996 Eurobarometer, which was conducted by a Concerted Action of the European Commission (BI04/CT95/0043) and 'Biotechnology and the European Public' and was coordinated by Martin Bauer, John Durant and George Gaskell, London, UK.

\section{References}

K. Asp, Mäktiga massmedier: studier $i$ politisk opinionsbildning.(Akademikerlitteratur, Stockholm, 1986).

M. Bauer ed. Resistance to new technology - nuclear power, information technology, biotechnology. (Cambridge University Press, Cambridge, 1995).

Biotechnology and the European Public Concerted Action Group, 'Europe ambivalent on biotechnology'. Nature 387 (1997), 845-847.

M. Djerf Pierre, Gröna Nyheter. Miljöjournalistiken $i$ televisionens nyhetssändningar 1961-1994. (Göteborgs Universitet, Göteborg,1996: 371).

J. Durant, A. HansenandM. Bauer,'Public understandingof new genetics', in The troubled helix. Social and psychological implications of the new human genetics, eds. T. Marteau and M. Richards, (Cambridge University Press, Cambridge, 1996).

E. Einsiedel, A. Allansdottir, N. Allum, M. Bauer, W. Berthomier, A. Chatjouli, S. de Cheveigné, R. R. Downey, J. M. Gutteling, M. Kohring, M. Leonarz, E. Manzoli, A. Olofsson, A. Przestalski, T. Rusanen,
F. Seifert, M. Stathopoulou, M., and W. Wagner, 'Brave new sheep - the clone named Dolly', in Biotechnology - the making of a global controversy, eds. M. W. Bauer and G. Gaskell, (Cambridge University Press, Cambridge, 2002).

B. Fjæstad,'Biotechnology and the European public', in Gene technology and the public, eds. S. Lundin and M. Ideland, (Nordic Academic Press, Lund, 1997).

B. Fjæstad B. andS. Olsson, Därför gillar vi inte gentekniken. Forskning \& Framsteg 6 (1997), 11-15.

S. M. Friedman, 'The journalist's world', in Scientists and journalists. Reporting science as news, eds. S. M. Friedman, S. Dunwoody and C. L. Rogers, (The Free Press, New York, 1986).

W. Gamson, W. and A. Modigliani, 'Media discourse and public opinion in nuclear power: aconstructivist approach', American Journal of Sociology 95 (1989), $1-37$.

C. Geertz, The interpretation of culture, (Basic Books, New York, 1973).

K. Giritli-Nygren and A. Olofsson, 'Intersectional approaches in health-risk research: a critical review', Sociology Compass 8(9) (2014), 1112-1126.

M. Gutteling and O. Wiegman, Exploring risk communication, (Kluwer Academic Publishers, Dordrecht, 1996).

A. Hansen,'The media and the social construction of the environment', Media, Culture and Society, 13, (1991), 443-458.

A. Hansen, 'Journalistic practices and science reporting in the British press', Public Understanding of Science 3, (1994), 111-134.

H. M. Kepplinger, 'Artificial horizons: how the press presented and how the population received technology in Germany from 1965-1986', in The mass media in liberal democratic societies, ed. S. Rothman, (Paragon House, New York, 1992), 155.

M. Kohring, 'Science journalism and journalism science', PCST-Conference, plenary lecture. (Berlin, 1998-0917: 10).

K. Krippendorff, Content analysis. An introduction to its methodology, (SAGE Publications, Newbury Park, 1980).

G. E. Lang and K. Lang, 'Watergate: an exploration of the agenda-building process', in Agenda setting. Readings on media, public opinion and policymaking, eds. D. L. Protess and M. McCombs, (Lawrence Erlbaum Associates, Hillsdale, 1991).

S. Ljungdahl and A. Sonesson, Belgisk blå och vit boskap, (SLU, Ulltuna, 1995).

S. A. Lowery and L. M. De Fleur. Milestones in mass communication research, 2nd. ed., (Longman, New York, 1988).

D. McQuail, Mass communication theory. An introduction, 3d ed. (SAGE, London, 1994).

E. Montelius and K. Giritli Nygren, "Doing" risk, "doing" difference: towards an understanding of the intersections of risk, morality and taste', Health, Risk \& Society, 16(5) (2014).

D. Nelkin, Selling science: how the press covers science and technology, (Freeman, New York, 1995). 
A. Olofsson and S. Olsson, 'The new biotechnology: media coverage and public opinion', in Public perceptions of science, biotechnology and a new university, ed. B. Fjæstad, (Mid Sweden University, Östersund, 1996:10).

A. Olofsson, J. O. Zinn, G. Griffin, K. Giritli Nygren, A.Cebulla and K. Hannah-Moffat, 'The mutual constitution of risk and inequalities: intersectional risk theory', Health, Risk \& Society 16(5), (2014), 417-430.

G. Ruhrmann, 'Genetic engineering in the press. A review of research and results of a content analysis', in Biotechnology in public. A review of recent research, ed. J. Durant, (Science Museum,London, 1992).

S. Öhman, Public perception of gen e technology-on the edge of risk society,(Umeå University, Umeå, 2002).

S. Öhman, K. Giritli Nygren and A. Olofsson, 'The (un)intended consequences of crisis communication in news media - a critical analysis'.Critical Discourse Studies 13(5) (2016), 515-530.

\section{News media}

Dagens Nyheter, 1995-09-15, p. 8.

Dagens Nyheter, 1995-11-07, p. A05.

Expressen, 1996-06-12, p. 21.

Göteborgs-Posten, 1996-04-09, p. 4.

Svenska Dagbladet, 1996-03-31, p. 8.

Svenska Dagbladet, 2006-10-27, p 4.

Expressen, 2010-02-11, p 7.

Lantbrukets affärstidning, 2015-03-17, p 8. 